\title{
Research Status Analysis of Project Course for Electrical and Mechanical Professions
}

\author{
Xinlin $\mathrm{He}^{1, \mathrm{a}^{*}}$, Miao Shang ${ }^{2, \mathrm{~b}}$ \\ ${ }^{1}$ Mechanical and electrical technology, Xijing University, Xi'an, China \\ ${ }^{2}$ Mechanical and electrical technology, Xijing University, Xi'an, China \\ a153789939@qq.com, b445700839@qq.com \\ *The corresponding author
}

Keywords: Higher education; Mechanical and electrical professional; Project teaching; Business practices; Curriculum reform

\begin{abstract}
Project teaching pays attention to the cultivation of students' vocational skills, and the project teaching pay attention to teaching thought transformation of "student-centered". Project teaching has changed the traditional teaching mode. The project teaching of higher vocational colleges which will need to be equipped with the corresponding project. The project teaching need construction of project course for development of project teaching. The implementation of the project teaching needs effective operation of project course, and the development of the higher needs constant feedback and revision for project course. In this article, the project teaching of mechanical and electrical professional is carried on the simple introduction; Project course is carried on basic research ; Project course are analyzed in the practice application; The development of project course is described. Finally pointed out that: the development of mechanical and electrical professional need to cooperate the project teaching, and the implementation of the project teaching need reasonable setting of project course. The research of project course of mechanical and electrical professional is of great significance for improving the students' comprehensive ability and adapt to the rapid development of economy.
\end{abstract}

\section{Introduction}

With the development of the curriculum reform in China, experts and scholars in the field of education and teaching in higher vocational colleges teachers who will gradually concern project teaching. At present, the project teaching has achieved fruitful research results in theory and in practice [1]. Project pays attention to the cultivation of the students' vocational skills, and project teaching pay attention to "student-centered" teaching thought transformation. Project teaching is suitable for the teaching reform of modernization in our country, and project teaching to adapt to the information and the rapid development of network in our country. The teaching of higher vocational colleges by project, which requires a corresponding project curriculum and the matching. So the project to carry out the need for the construction of the project curriculum teaching, the implementation of the project teaching need effective operation of project-based curriculum, the development needs of the project curriculum project teaching feedback and revision. Project curriculum is the premise and foundation of project teaching, at the same time project course is one of the ways to promote the electrical and mechanical professional teaching reform.

\section{Basic research of project course}

The project course is compared with traditional discipline course and there is a curriculum model. Program designed to effectively train students' vocational ability. Project curriculum model based on work task as the main study way. Project curriculum through innovation to strengthen the course content and the correlation between work, so as to achieve the purpose of integration of theory and practice. Project course tasks must revolve around this practice center for when choosing and organizing curriculum content [2]. The specific construction form of project curriculum to clear the 
connotation of the project course. Project course is broken into students accept the task, independently complete the task, results show and learning evaluation and so on. Project curriculum emphasizes the integration of "teaching, learning and doing", described need more links courses at the same time, the project of "working process" according to the specific project build. The objectives of the reform of higher vocational education curriculum project and adjust accordingly. From the initial project curriculum single-door project course content into the overall design project goal. Project course objective is to build more key project curriculum system as a whole [3].

From the perspective of project choice and organization of the course content, the project is to study the key technology of project curriculum development in action, the construction of learning program. The current vocational colleges in the project design, universal existence two tendencies: one is to leave work tasks, the choice of project is fully professional knowledge centered. The other is a project curriculum design is based solely on task as the center, at the same time project curriculum needs to revolve around each task of learning [4]. The ultimate goal of vocational ability training or serve the needs of local industrial development. Therefore the specific teaching content should be combined with local practice project design to the content of the professional courses [5]. The course was conducted training students' ability in the corresponding specific professional, at the same time examination by implementation requires a specific project in the process of teaching.

Project curriculum setting is not only the change of the form such as course name, course gate number, also fundamentally implementation and reflect the law of the task is complete and the requirements of teaching goals. On curriculum order, project course is both teaching law and strictly follow the logic of job fair [6]. Period allocation and project course also should fully consider the frequency and the difficulty of the task, change "form of teaching" to "substantial" improve the capacity. In this way, the project teaching course system to form the scientific project. The design of the project once out of the specific work tasks, that can guarantee the good teaching effect. Project design is the key to the choice of projects and work tasks matching mode. Project design common way of matching are "circulation" and "segmented" and the corresponding type. The project design of circulating as shown in figure 1(a), the project design of sectional shown in fig. 1(b), the project design of the corresponding type is shown in figure 1(c). In the specific course design, project design may cross use these three models. But no matter when to take that kind of model for project design, must fully consider the student's professional qualification. So you should not set too big project, project curriculum project curriculum can't have more theoretical knowledge at the same time.

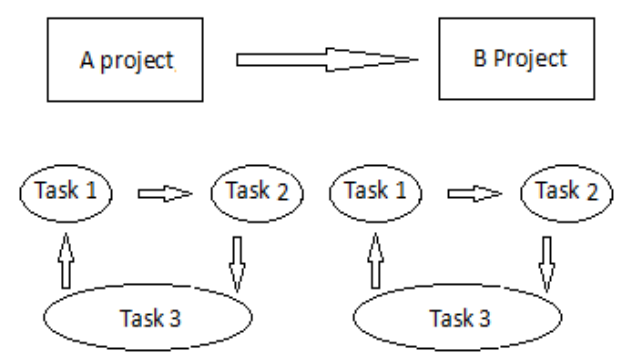

(a) Circulation

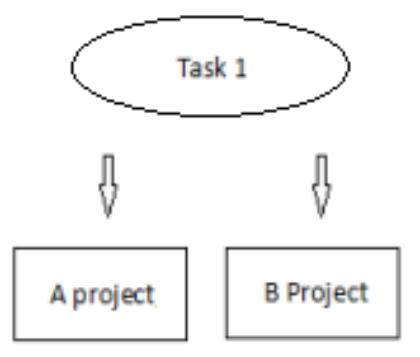

(3) Corresponding type

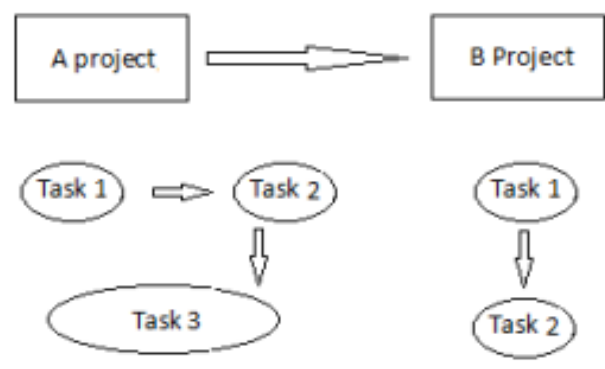

(b) Sectional

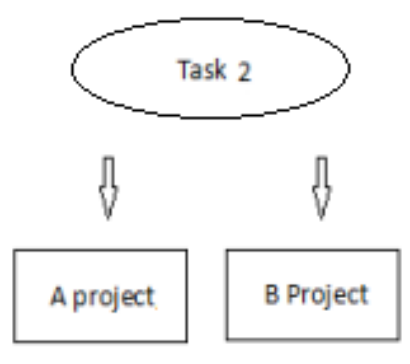
(n)

Figure 1. Project design common way of matching 


\section{Application Analysis of Project Course}

Specific application of the course project mainly embodied in two aspects. Is a kind of vocational colleges, head of the managers and professional in schools, professional or professional group of level to promote curriculum project [7]. Another kind is the major subject in the concrete course in the teaching project. In which aspects, are involved in the concrete implementation teaching staff, teaching management mode, hardware conditions and mechanism of university-enterprise cooperation multiple resistance.

(1) On the teaching of inertia, ordinary teachers through the disciplinary curriculum system of general education. Teachers in higher vocational colleges has already formed the subject knowledge according to the logical arrangement of inertia, the content of the course and the teaching of higher vocational teachers have chapter theory teaching of inertia.

(2) On the ability to work, the enterprise practice experience of unseen spent the most of the teachers in higher vocational colleges can't develop the project fits the course objectives.

(3) Evaluation in higher vocational colleges of traditional pattern is the roadblocks that stand in front of the project construction.

In the current teaching management mode of higher vocational colleges is the important factor for the formation of resistance. In course of teaching process of the project of integrity for the split [8]. On the internal layout, only the experimental area is set up, discussion and teaching experiment training room has not been set up. These hindered the integration of the theory of practice teaching. Most of the higher vocational colleges have recognized enterprise enrolled, the importance of cooperation in running schools. Curriculum design departure from the actual jobs in part working content and working process. Task analysis, the rationality of the curriculum structure design, program development, is also unable to guarantee. Project course effectively promote not only confined to the micro-level of partial reforms, more dependent on associated with system of teaching management, teacher management system and a series of institutional change together. Higher vocational colleges need to according to the project curriculum needs to integrate software and hardware resources. Higher vocational colleges need to re-examine the introduction of talent standard, adjust the institutions, promote the comprehensive reform step by step.

\section{Development of Project Curriculum}

From at home and abroad about the document of project course study, the researchers on the project curriculum on the fruitful discussion research, and have gained many meaningful results.

(1) On the theoretical research, the existing research take constructivism, technical philosophy, professional, scientific, beneficial research results and the latest research progress in the theory of learning. From the contact theory, structure theory, the Angle of the comprehensive and the theory of the clear answer "what is the theoretical basis of the project curriculum". Project course is the advantage of the depth of explanation, and indicate the direction of the vocational education curriculum reform project course. But today's study lack of ideal and reality in the process of project curriculum reform research problems, no forming theory of project implementation process [9].

(2) On the microcosmic research, more focused on the existing literature from a macro perspective of curriculum structure architecture. The specific course of practical ways as follows: task analysis to curriculum structure arrangement, learning program design. The curriculum development of micro link lack of in-depth and detailed discussion. Project course is superficial, stalled [10].

(3) In study of adaptive, all and all courses should adopt project curriculum model has gradually become to get rid of the erroneous tendency. Project course gradually from professional type, and nature. But few scholars can in-depth analysis on the difference between secondary and higher vocational curriculum project, project curriculum reform still has certain blindness and one-sidedness. 
(4) On the systemic research, although the researchers have begun to holistic thinking in systemic project curriculum reform, but still lack of the further construction of curriculum system [. Both internal and external environmental factors of the curriculum system as a whole to improve literature are much rarer.

\section{Conclusions}

The project teaching has achieved fruitful research results in theory and in practice. Project teaching is suitable for the teaching reform of modernization in our country, and project teaching to adapt to the information and the rapid development of network in our country. The project teaching has changed the traditional teaching mode, and it is adapt to the development of the market for the rapid development of economy in our country. The project teaching need construction of project course for development of project teaching. The implementation of the project teaching needs effective operation of project course, and the development of the higher needs constant feedback and revision for project course. In this article, the project teaching of mechanical and electrical professional is carried on the simple introduction; Project course is carried on basic research ; Project course are analyzed in the practice application; The development of project course is described. Finally pointed out that: the development of mechanical and electrical professional need to cooperate the project teaching, and the implementation of the project teaching need reasonable setting of project course. Therefore, the research of project course of mechanical and electrical professional is of great significance for improving the students' comprehensive ability and adapt to the rapid development of economy.

\section{References}

[1] J.B.Wang, H.T.Yang:New Field of Overseas Investment-New Trend of Transnational Higher Education (DongYue Review, China, 2012)

[2] Wang Boqing. 2012 Chinese university students' employment report [M]. Beijing: social sciences academic press, 2012:46.

[3] sichuan Zhou Qin. Higher vocational education curriculum mode and select [D]. Nanjing: nanjing normal university, 2007:15 to 16 .

[4] mei-yun zhang. Tumor disease and reform path of the curriculum in colleges and universities [[J]. Journal of China's higher education, 2010 (17) : 33-34.

[5] Chen Lanjian. Comprehensive vocational ability orientation of higher vocational curriculum reform research [[D]. Nanjing: nanjing university of science and technology, 2008:20.

[6] new before the king. "training mode of higher vocational education person diao 'construction M] shantou, shantou university press, 2002:230.

[7] Huang Kexiao. Introduction to vocational and technical education course [M]. Shanghai: east China normal university press, 2000:136.

[8] ma. The curriculum system of higher vocational project research [M]. Beijing: Beijing university of science and technology press, 2011:25 to 37.

[9] Chun Zhou. Jiang machinery innovation ability structure of the system analysis of higher vocational students. School education in China, 2011 (6) : 56-58

[10] Xiang wei Liu. Based on the working process of the development of higher vocational machinery manufacturing professional curriculum strategy. Education and career, 2011 (11) : 138 139. 